\title{
PERUBAHAN KARAKTER RANGGA SEBAGAI SALAH SATU BENTUK PROSES KREATIF MIRA LESMANA \\ DALAM FILM ADA APA DENGAN CINTA 2 (2016)
}

\author{
Sugeng Nugroho \\ Dosen Pascasarjana dan Jurusan Pedalangan \\ Institut Seni Indonesia Surakarta \\ No. HP.: 085229783007,E-mail: sgngnugroho@gmail.com \\ Danissa Dyah Oktaviani \\ Mahasiswa S-2 Pengkajian Film Pascasarjana Institut Seni Indonesia Surakarta \\ No.HP.: 081222301643,E-mail: oktavcan@gmail.com
}

\begin{abstract}
Abstrak
Mira Lesmana, produser terkemuka Indonesia, membuat gebrakan dengan merilis dan menulis sendiri cerita film Ada Apa dengan Cinta 2. Kekuatan film ini tidak semata-mata bersandar dari sekuel sebelumnya, namun juga dikemas dengan aliran cerita yang menarik. Alur yang menggantung dalam sekuel sebelumnya merupakan peluang besar untuk mengembangkan kreativitas. Bentuk kreativitas Mira Lesmana dalam menulis cerita film ini adalah untuk mengubah karakter utama, Rangga. Karakter Rangga sengaja dibuat berbeda didasari tokoh Cinta. Perubahan karakter Rangga terjadi pada awal dan akhir cerita. Perubahan karakter Rangga dapat dilihat dari ekspresi, dialog, dan tanggapan dari orang lain yang mengetahuinya sehingga dapat diketahui perubahan karakter dasar (karakter tokoh 3D) adalah fisiologis, sosiologis, dan psikologis. Perubahan karakter Rangga dapat diketahui melalui pendekatan psikologi yang di dalamnya memuat karakterisasi tokoh, konstelasi tokoh, dan konsepsi tokoh. Melalui pendekatan tersebut akan nampak struktur, dinamika, dan perkembangan tokoh Rangga sehingga dapat diketahui perubahan karakter Rangga yang berdampak terhadap kehidupannya dalam film ini.
\end{abstract}

Kata kunci: perubahan karakter, Rangga, karakter 3D

\begin{abstract}
Transformation of Rangga's Character as One of Creative Processes from Mira Lesmana in the Film 'What's Up with Love? 2'(2016). Mira Lesmana, an Indonesia's leading producer, made a breakthrough by writing the story herself and released the film "What's Up with Love? 2". The strength of the film is not simply leaning on the previous sequel, but also packed with interesting flow of stories. The hanging flow on the previous sequel is a great opportunity to develop creativity. Mira Lesmana's form of creativity in writing this movie is to change the main character, Rangga. Rangga's character is deliberately made different, based on the character of Cinta. The changes of Rangga's character occur at the beginning and at the end of the story. The change can be seen from the expression, dialogue and feedback from others who acknowledge it so that the changes of the basic character (3D character) are physiological, sociological, and psychological. The change can be known through the psychological approach which includes the characterization of the characters, constellation of characters, and conception of characters. Through this approach, the structure, the dynamics and the character's development of Rangga can be seen, thus its change which affect his life in this movie can also be seen.
\end{abstract}

Keyword: character changes, Rangga, 3D character 


\section{PENDAHULUAN}

Mira Lesmana, produser film terkemuka di Indonesia membuat kehebohan bagi pencinta film tanah air dengan film terbarunya. Sebelumnya tidak terlintas dalam pikiran Mira Lesmana untuk membuat film ini. Namun, semua berubah ketika terdapat petikan kejadian yang memantikkan ide kreatif Mira Lesmana dan memutuskan untuk memproduksi film ini. Film ini merupakan sebuah sekuel film Mira Lesmana yang menjadi awal kebesaran namanya, yaitu Ada Apa dengan Cinta 2 (Lesmana, 2016).

Film Ada Apa dengan Cinta (2002) merupakan tonggak kebangkitan perfilman Indonesia. Disebut demikian karena film ini membangkitkan semangat orang untuk menonton film di bioskop. Film ini berkisah kemelut kehidupan remaja SMA yang dibuat dengan cerita yang menarik dan diimbangi dengan karakter tokoh yang kuat. Karakter utama dalam film ini bernama Cinta dan Rangga. Karakter Cinta digambarkan sebagai remaja putri yang cantik, pandai, dan hidup berkecukupan, sedangkan Rangga digambarkan sebagai tokoh yang dingin, tertutup, dan misterius.

Kisah drama cinta dalam film ini diakhiri dengan happy ending. Perasaan Cinta dan Rangga saling berbalas dan berujung pada sebuah tindakan Rangga sebagai ekspresi cintanya kepada Cinta. Walaupun demikian, akhir cerita film Ada Apa dengan Cinta (2002) menggantung. Film ini diakhiri dengan penantian Cinta terhadap kepulangan Rangga yang melanjutkan kuliah di Amerika. Hal tersebut yang menjadi peluang bagi penulis film Ada Apa dengan Cinta 2 (2016), Mira Lesmana untuk melakukan kreativitas terhadap alur cerita. Salah satu jalan yang ditempuh oleh sang penulis skenario adalah dengan mengubah karakter tokoh Rangga. Dengan mengubah karakter tokoh dengan cara mempersepsi tokoh bisa membatasi atau mengembangkan hakikat sebuah cerita (Noble, 2006). Dalam menetapkan karakter Rangga, Mira
Lesmana melakukan survei untuk membangun cerita yang sesuai. Hal tersebut dilakukan agar cerita memiliki kredibilitas yang lebih tinggi bila penonton bisa mengidentifikasikannya dengan kenyataan sehari-hari (Sidarta, 2003).

Film Ada Apa dengan Cinta 2 mendapatkan ketenaran melalui sekuel film sebelumnya. Namun demikian, film ini bukanlah sebuah film karbitan yang menumpang tenar film pendahulunya. Film Ada Apa dengan Cinta 2 juga memiliki kekuatannya sendiri yang dibangun baik dari segi cerita maupun teknik sinematografinya. Film ini digarap oleh sutradara dan penulis yang berbeda sehingga tidak mengherankan menghasilkan sensasi menonton yang berbeda pula.

Salah satu kekuatan film Ada Apa dengan Cinta 2 terletak pada kekuatan cerita. Sebuah persyaratan yang sangat penting yang dituntut dalam sebuah cerita yang bagus ialah bahwa cerita itu harus mampu mengikat dan mengungkung perhatian penonton (Boggs, 1992). Ditulis sendiri oleh sang produser, film Ada Apa dengan Cinta 2 menjadi film yang banyak ditunggu kehadirannya di layar bioskop tanah air. Mira Lesmana sebagai seorang produser dan penulis naskah memiliki wewenang yang besar dalam menentukan alur cerita dan alur produksi. Menulis film sekuel merupakan tugas yang memiliki tingkat kemudahan dan kesulitannya tersendiri. Alur besar cerita inti sudah terbentuk dari awal merupakan sebuah kemudahan. Namun, membuatnya berbeda dari sekuel sebelumnya merupakan sebauh pekerjaan rumah yang cukup rumit.

Skenario film yang disebut screenplay atau script diibaratkan seperti cetak biru (blue print) bagi insinyur atau kerangka bagi tubuh manusia (Sumarno, 1996). Cerita dalam film merupakan unsur naratif yang penting, penonjolan karakter dalam cerita adalah salah satu jalan yang dapat dipilih. Kepintaran Mira Lesmana nampak dalam menulis cerita dan melihat peluang bahwa karakter pemain film Ada Apa dengan Cinta sangat kuat terutama 
karakter-karakter pemain utamanya. Walaupun demikian, Mira Lesmana tetap melakukan sebuah gebrakan dengan mengubah karakter Rangga dalam sekuel Ada Apa dengan Cinta 2 ini. Perubahan karakter Rangga sangat bertolak belakang, namun dikemas dengan sangat halus dalam sebuah pergumulan konflik batin yang dalam.

Dalam memahami perubahan karakter yang dilakukan Mira Lesmana dapat dilakukan dengan cara melihat film Ada Apa dengan Cinta dan Ada Apa dengan Cinta 2 berulang-ulang terfokus pada karakter Rangga kemudian mencari adegan dalam scene yang menggambarkan perwatakannya dengan pendekatan psikologi dengan menempatkan film sebagai sebuah teks. Teori yang digunakan meliputi analisis 3D karakter yang termuat dalam karakterisasi tokoh, konstelasi tokoh, dan konstelasi tokoh. Marquaß (1997) dalam (Inna, 2005) berpendapat bahwa: dalam menganalisis tokoh pada teks prosa harus diperhatikan ciri-ciri apa saja yang tokoh itu tunjukkan (karakterisasi) dan bagaimana hubungan antartokoh yang satu dengan yang lain (konstelasi). Selain itu, juga termasuk bagaimana cara pengarang merancang tokoh-tokoh (konsepsi).

\section{PEMBAHASAN}

\section{Pola Perubahan Karakter Tokoh Rangga}

Salah satu keunikan dalam film $A d a$ Apa dengan Cinta 2 adalah bahwa tokoh Rangga merupakan tokoh pembawa alur cerita. Pokok dari cerita adalah kisah perjuangan protagonis melawan problema utama sampai tokoh utama mencapai tujuan/goal atau gagal (Biran M. , 2006). Dalam membawa cerita, Mira Lesmana memutuskan melakukan pembelokan cerita. Rangga yang dikisahkan kembali ke Indonesia untuk menemui ibunya akhirnya bertemu dengan Cinta. Pembelokan cerita inilah yang berperan dalam proses perubahan karakter Rangga. Perubahan karakter dan sikap telah membawanya terhadap kehidupannya yang baru.
Cerita yang menarik adalah cerita yang mampu menampilkan karakter yang kuat (Fitryan, 2009). Penulisan karakter Rangga akan dibagi ke dalam dua bagian besar, yaitu bagian permulaan dan akhir cerita yang menunjukkan dengan sangat jelas perubahan karakter Rangga. Namun, pada awal film perubahan karakter Rangga sudah dapat dirasakan dibandingkan dengan sekuel pendahulunya baik dalam karakterisasi, konstelasi, maupun konsepsinya.

Minderop (1996) mengklasifikasikan watak para tokoh dalam tiga dimensi, yaitu dimensi fisiologis, psikologis, dan sosiologis. Tokoh atau individu dalam karya film meskipun bersifat imajiner atau khayalan penulis, tetapi memiliki sisi psikologis sama seperti individu dalam dunia nyata. Unsur-unsur psikologis inilah yang akan dipaparkan dalam pembahasan ini, yakni bagaimana struktur kepribadian, dinamika kepribadian, dan perkembangan kepribadian tokoh utama Rangga dalam film Ada Apa dengan Cinta 2.

\section{Karakterisasi Tokoh}

1. Ciri-Ciri Lahiriah

Sebagai tokoh utama dalam film cerita drama, Rangga dapat digolongkan tipe leptosom, yaitu mengarah pada tubuh yang tinggi dan kurus sehingga tulang-tulangnyapun terlihat menonjol dan wajahnya cenderung memelas dan sedih (Lutters, 2004). Rangga dikisahkan sebagai seorang laki-laki dewasa berumur 30 tahun. Tokoh Rangga sudah menjadi idola baru sejak kemunculannya pada sekuel pertama film ini pada tahun 2002. Rangga digambarkan berbadan tinggi, putih, dengan rambut ikal. Raut wajahnya lebih tanpa ekspresi dan menyimpan banyak tekanan dan masalah. 


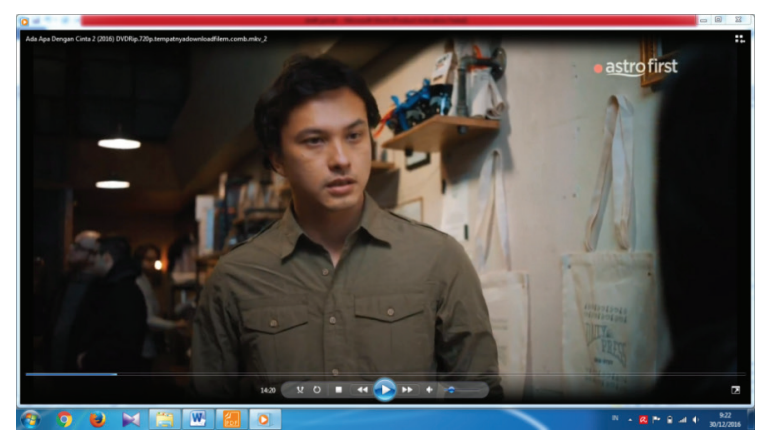

Gambar 1. Fisiologi tokoh Rangga Capture timecode 00:14:19

Mira Lesmana kembali memilih Nicholas Saputra sebagai pemeran Rangga pada sekuel film Ada Apa dengan Cinta 2. Nicholas Saputra sangat baik memerankan Rangga dengan karakter yang berbeda dibantu make up dan wardrobe yang baik sehingga karakter fisiologis Rangga dapat diwujudkan dengan baik. Rangga dalam Ada Apa dengan Cinta memiliki penampilan yang lebih rapi dan tidak banyak menggunakan aksesoris. Penampilan Rangga setelah empat belas tahun kemudian disesuaikan dengan latar belakang pendidikan, umur, pekerjaan, dan lingkungan sosial yang membentuknya.

Rangga yang berusia 30 tahun sering menggunakan kemeja sebagai tanda bahwa dirinya sedang berada di lingkungan formal pekerjaannya. Pada saat pengambilan gambar di Amerika. Rangga adalah seorang pemilik sebuah kafe. Hal tersebut dapat dilihat dari latar belakang tempat yang digunakan dalam scene di atas. Raut wajah acuh tak acuh dan dingin tidak lagi nampak di wajahnya seperti karakter sebelumnya. Raut wajah yang ditampilkan dengan pembawaan tenang, namun ramah.

Mira Lesmana juga melakukan perubahan karakter Rangga yang nampak pada awal dan akhir cerita yang dapat dilihat dari raut wajahnya. Pada awal cerita raut wajah Rangga mulai bisa menerima kehidupan lamanya dengan rasa bersalah yang dipikulnya seumur hidup. Pada akhir cerita raut wajah Rangga berubah bahagia karena akan menjalani hidup sesuai dengan harapannya.

\section{Ciri-Ciri Sosial}

Perubahan fisik karakter Rangga dipengaruhi oleh lingkungan sosialnya. Rangga harus menyesuaikan kehidupan barunya dalam kondisi yang berbeda. Film Ada Apa dengan Cinta menceritakan Rangga adalah siswa SMA yang pandai, berkecukupan, dan memutuskan untuk kuliah di luar negeri bersama ayahnya (single parent). Di kehidupan asmaranya, Rangga berjanji segera kembali untuk Cinta, kekasihnya. Pada film Ada Apa dengan Cinta 2 bertentangan dengan semua itu. Ayahnya meninggal, kuliahnya kacau, tekanan keluarga Cinta yang berujung pada perpisahan keduanya, dan kehadiran kembali sosok ibu yang sudah lama tidak lagi dianggap dalam hidupnya mengubah sebagian besar karakter Rangga remaja.

Sisi sosiologis tokoh Rangga di sisi lain adalah seorang wirausaha yang bekerja sama membuka bisnis kafe, tinggal sendiri menetap di Amerika, belum menikah dan broken home, ayahnya meninggal, ibunya menikah lagi dan memiliki anak bersama Sukma, hobi menulis buku dan puisi. Perubahan ciri-ciri sosial pada diri Rangga dipengaruhi oleh perubahan besar

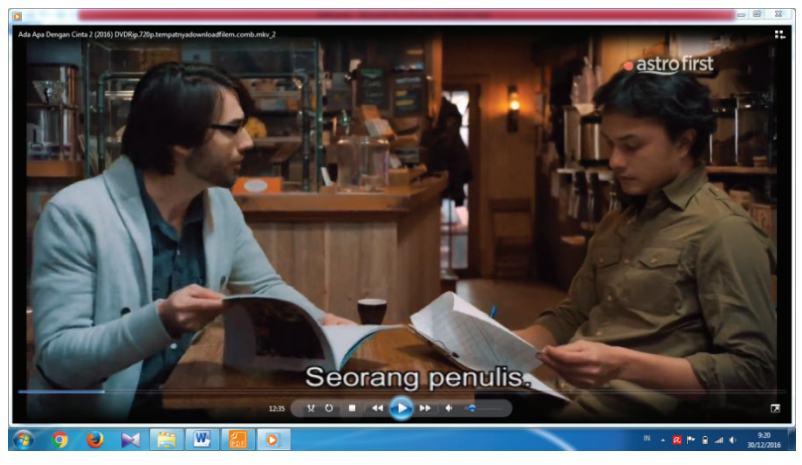

Gambar 2. Rangga sedang berdiskusi dengan rekan kerja. Capture timecode 00:12:29 
dari sisi psikologis Rangga terhadap masalah terbesar dalam hidupnya.

Masalah terbesar dalam hidupnya adalah perpisahannya dengan orang-orang terdekat. Ayah Rangga meninggal dan jalinan cintanya dengan Cinta kandas. Rangga bertahan hidup menetap di Amerika karena sudah tidak ada lagi tempat yang memberikan kedamaian hati di Indonesia. Namun, semua berubah saat Rangga menemukan semangat hidupnya pada Cinta. Rangga seperti menemukan harapan untuk kembali bahagia di Indonesia. Pusat kebahagiaan Rangga adalah Cinta. Cinta yang membutnya bisa berdamai dengan ibunya. Namun saat Cinta sudah tidak lagi menghangatkan hatinya, ibunya tidak bisa menjadi alasannya untuk bertahan di Indonesia. Rangga akhirnya memutuskan untuk kembali ke Amerika.

Perbedaan karakter yang nampak pada tokoh Rangga berubah saat di akhir cerita. Rangga lebih ramah dan mudah bersosialisasi dengan orang lain. Salah satunya adalah Rangga dengan senang hati menaikkan gaji pegawainya dan menerima pelukan orang yang sebenarnya merupakan karyawannya. Selain itu, Rangga terlihat lebih mudah untuk mengungkapkan isi hatinya sehingga orang-orang di sekitarnya mengenalnya lebih baik sehingga Rangga bisa hidup lebih dinamis dengan memahami dan dipahami orang lain.

\section{Psikologi}

Tokoh dilihat dari sisi psikologis, yaitu melihat dari sudut pandang psikis tokoh meliputi watak, kegemaran, mentalitas, standar moral, temperamen, ambisi, kompleks psikologis yang dialami, keadaan emosinya, dan sebagainya (Wicaksono, 2014). Dalam film Ada Apa dengan Cinta 2, Rangga sedang

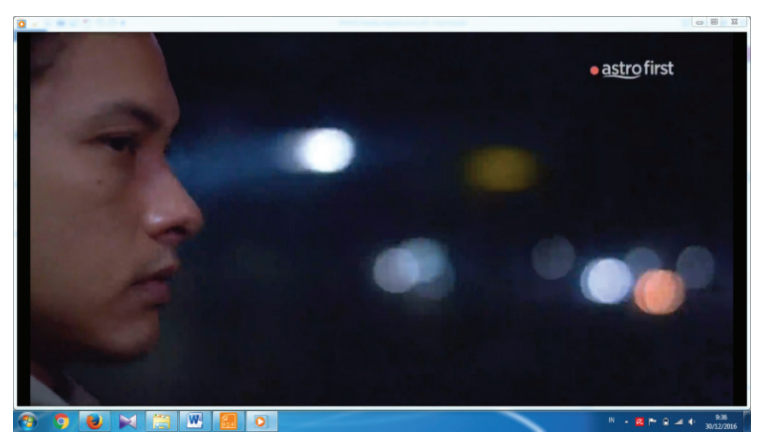

Gambar 3. Raut wajah murung Rangga Capture timecode 00:26:34

mengalami pergumulan hati. Berbeda saat sekuel pertamanya, Rangga menemukan sosok Cinta dan selalu dikejar oleh Cinta. Namun semua berubah, Rangga dengan yang ada di dalam pikiran dan perasaannya akan memperjuangkan cintanya. Dalam prosesnya terdapat perasaan, sikap, dan watak Rangga yang muncul dalam film.

Membaca sisi psikologis Rangga dapat dilakukan dengan cara membaca ekspresi wajahnya. Wajah Rangga terlihat penuh makna dan menyimpan banyak luka. Sangat sulit bagi Rangga untuk berdamai dengan keadaan yang dirasakan sangat tidak adil. Penyesalan, kekecewaan, dan rasa bersalah yang di dalam diri Rangga tergambar di sepanjang jalannya film. Pada awal jalannya cerita, rumah Cinta adalah tempat pertama yang dikunjungi Rangga di Indonesia. Rasa bersalah dan hasratnya pada Cinta menuntunnya kembali kepada Cinta.

Rangga akhirnya memutuskan untuk kembali ke Indonesia. Kembali ke Indonesia merupakan keputusan yang berat karena ia memutuskan untuk menuju pusat rasa sakit hatinya selama ini. Sikap diam Rangga bukan lagi mencerminkan sebuah ketenangan, melainkan berubah menjadi sebuah kecemasan, penyesalan, dan ketakutan. Pergumulan hati Rangga yang melatarbelakangi ekspresi wajah tersebut. Rangga terang-terangan menunjukkan kepedulian baik terhadap perasaan rasa 
bersalahnya maupun peduli dengan sakit hati Cinta yang diciptakan. Rangga yang dulu sangat cuek kini dapat berani memulai dan memperjuangkan.

Perubahan sikap Rangga santai dan murah senyum banyak ditemukan pada scene adegan bersama Cinta. Ekspresi Rangga tidak lagi bisa menyembunyikan isi hatinya. Rangga merasa nyaman saat berada di dekat Cinta. Ekspresi ini benar-benar sulit ditemukan pada sekuel pendahulunya. Perubahan karakter ini sangat terasa dan menimbulkan efek tersendiri bagi penonton.

Rangga yang dingin juga diubah oleh Mira Lesmana. Di beberapa bagian diri Rangga digambarkan lebih santai. Gesture tangannya dimasukkan ke dalam saku celana, memakai kemeja, dan membawa kamera yang sering kali dibawa bagi seseorang yang gemar bepergian. Banyak adegan yang benar menunjukkan karakter dingin yang menempel pada diri Rangga mulai luntur saat banyak adegan yang tidak hanya menunjukkan dirinya tersenyum bahkan tertawa.

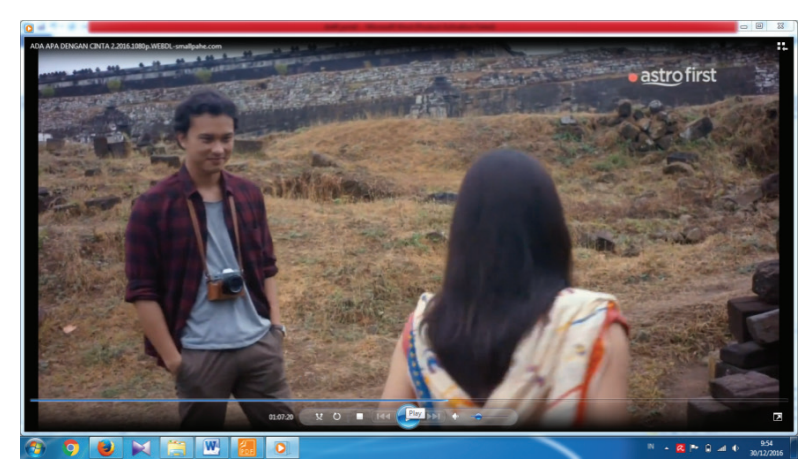

Gambar 4. Gesture santai Rangga Capture timecode 01:07:21

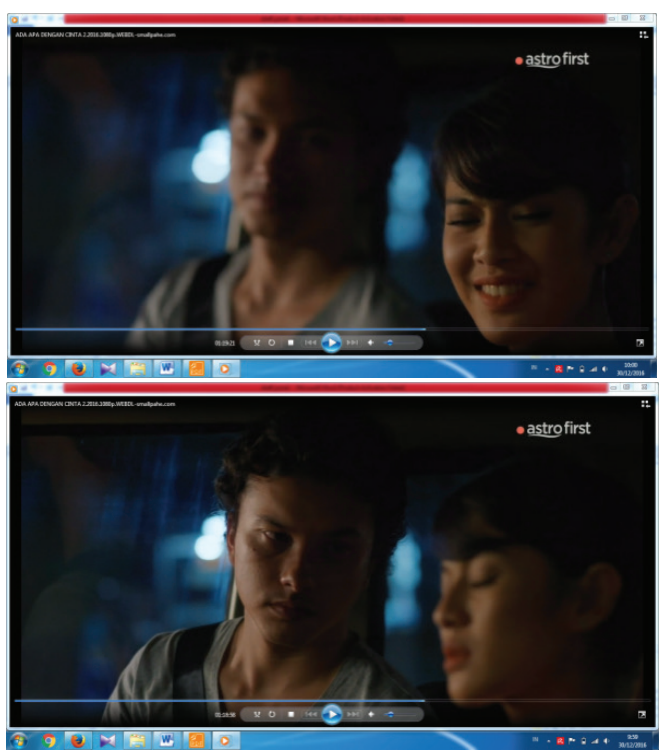

Gambar 5. Perubahan sifat Rangga melalui tokoh lain. Capture timecode 01:18:55 dan 01:19:22

Rangga: Baikan lagi boleh nggak? Kali ini baikannya pakai hadiah deh.

Cinta: Kalau kamu sinis itu saya sudah nggak heran lagi tapi kamu jadi bokis gini belajar dari mana sih? Apa hadiahnya?

Karakter Rangga juga dapat diketahui melalui tokoh lain. Sebagai tokoh yang paling dekat dengan Rangga, Cinta merasakan betul perubahan dalam diri Rangga. Hal tersebut nampak dari perubahan ekspresi Cinta dalam scene tersebut. Cinta yang awalya kesal dengan Rangga berubah tersenyum saat mendengar perkataan Rangga. Kutipan dialog di atas menunjukkan dengan jelas bagaimana Cinta terheran melihat perubahan karakter Rangga. Sebelumnya sifat lama Rangga kembali muncul saat Rangga menebak latar belakang Trian dengan benar dengan komentar dingin. Hal tersebut kemudian memantik pertengkaran lain antara Rangga dan Cinta.

\section{Konstelasi Tokoh}

1) Rangga dengan Cinta

Film ini terbagi dalam dua hubungan besar yang 


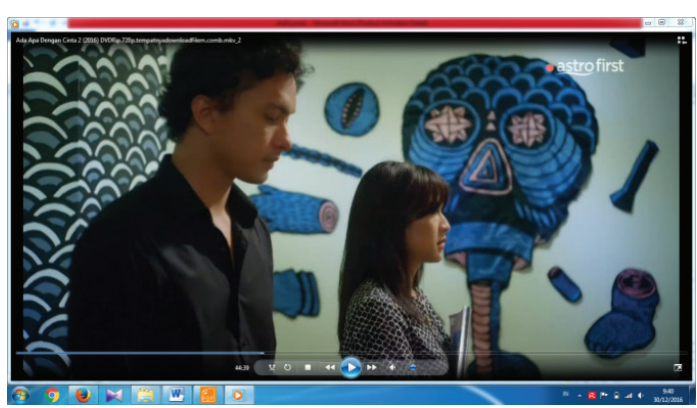

(a)

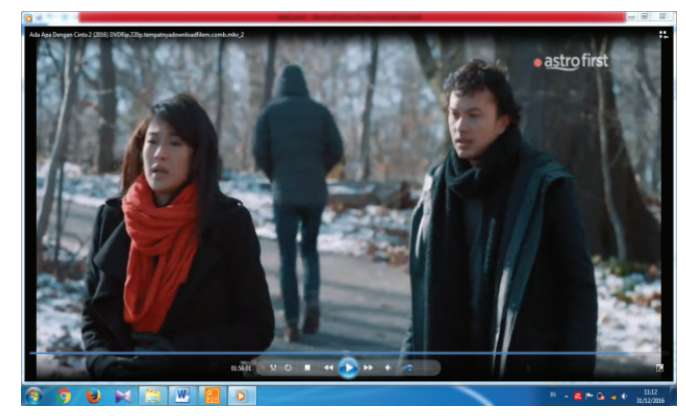

(b)

Gambar 6. Rangga mengejar Cinta di awal dan akhir cerita

Capture timecode: 00:44:40 dan 01:56:02

Dialog (a)

Rangga: Cinta.... Terlalu lama.

Cinta: Iya. Terlalu Lama.

Dialog (b)

(berlari dan mengejar Cinta)

Rangga: Cinta....

nampak sangat kontras pada awal permulaan dan akhir cerita. Pada awal cerita hubungan Rangga dan Cinta diceritakan tidak baik hingga Cinta tidak lagi mau bertemu Rangga yang dulu dikejarnya hingga Amerika. Perubahan yang terjadi adalah Rangga sekarang mengejar Cinta dan tidak lagi Cinta yang mengejarnya. Rangga memutuskan kembali ke Indonesia memulai dengan mengunjungi rumah Cinta yang ada di Jakarta. Hubungan Rangga dan Cinta merupakan inti cerita yang memberikan dampak besar terhadap perubahan dalam karakter Rangga baik terhadap dirinya sendiri, Cinta, maupun dengan tokoh yang lain.
Pada gambar di atas keduanya menunjukkan adegan Rangga mengejar Cinta untuk memperjuangkan cintanya. Rangga bahkan memulai percakapan terlebih dahulu. Perubahan sikap dan sifat Rangga inilah yang membawa Cinta kembali di sisinya. Kesalahan pada masa lalu harus dibayar mahal oleh Rangga. Oleh karena itu, Rangga sekuat tenaga nekat kembali hadir dalam hidup Cinta meskipun sadar bahwa Cinta sudah memiliki laki-laki lain.

Cinta: Kamu boleh ngomong sekarang Rangga: Saya akan coba jelasin semuanya tapi sambil jalan yuk

Dalam dialog di atas dapat diketahui bahwa Rangga sengaja membuat suasana lebih cair dan santai. Suasana memanas di kedai makanan membuat Rangga sadar bahwa emosi Cinta sudah mulai meninggi. Dengan suasana baru, Rangga bisa menjelaskan dengan lebih leluasa dan menjaga emosi Cinta. Cinta yang sudah merasa nyaman dengan hubungannya dengan Rangga akhirnya membuatnya memiliki waktu lebih lama untuk bersama.

Cinta: Ini saya mau diculik ke mana sih? Mau cerita tentang ibu kamu aja pakai sewa mobi segala.

Rangga: Ntar kalau naik motor rambut kamu rusak.

Dalam adegan yang lain, Perubahan karakter Rangga sangat nampak pada cuplikan dialog tersebut. Sifat dingin dan cuek Rangga sudah tidak nampak bahkan cenderung aktif dan santai. Rangga bisa membuat Cinta terkesan sehingga yang awalnya merasa dicampakkan akhirnya bersedia untuk diajak berkeliling kota Yogyakarta dengan alibi ingin bercerita tentang kisah ibu Rangga. 


\section{2) Rangga dengan teman-teman Cinta}

Hubungan Rangga dengan teman-teman Cinta tergolong tidak cukup baik. Pada sekuel pertamanya, Rangga mengira bahwa geng Cinta merupakan sekumpulan orangorang aneh dan menilai persahabatan mereka tidak akan bertahan lama. Anggapan itu tidak membuat sikap teman-teman Cinta sinis terhadap Rangga. Demi kebahagiaan Cinta, Karmen nekat menghubungi Rangga untuk menemui Cinta dan memberinya sebuah penjelasan perpisahan mereka sebelum Cinta menikah dengan Trian.

Karmen juga melakukan kontak hubungan dengan Rangga walaupun diungkapkan secara implisit dalam film. Sedikitnya empat kali Karmen menghubungi Rangga, yaitu menelepon Rangga di hotel untuk memberitahukan keberadaan mereka di Jogja, memberi kode posisi Cinta saat berada di pameran Eko Nugroho, memberi tahu jadwal liburan, dan berniat memperingatkan Rangga untuk menjaga Cinta. Kepedulian sahabatsahabat Cinta dijadikan jembatan pertemuan Cinta dan Rangga. Kepedulian sahabat-sahabat Cinta membuat Rangga dan Cinta dapat terhindar dari Trian (tunangan Cinta). Sahabatsahabat Cinta juga yang menyadarkan Cinta atas berartinya kehadiran Rangga di hidupnya.

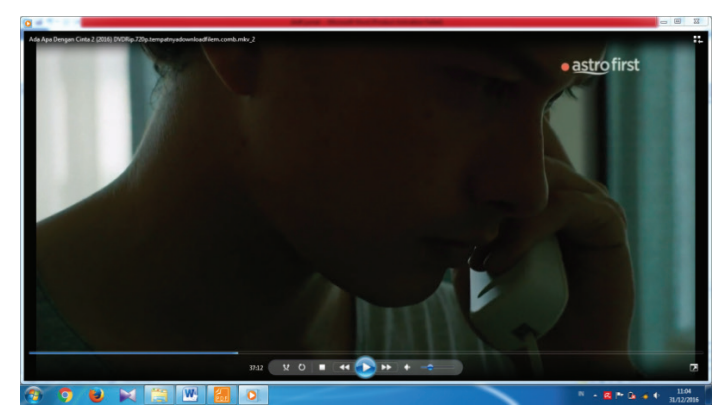

Gambar 7. Rangga menerima telepon dari Karmen Capture timecode: 00:37:12

\section{3) Rangga dengan Ibunya}

Dikisahkan sebagai anak yang ditinggal ibunya tanpa penjelasan sejak kecil, Rangga hidup bersama ayahnya dan membenci ibunya. Pertemuannya dengan Cinta mengubah semuanya, setelah Cinta bisa memaafkan semua kesalahan terbesar yang pernah dilakukan Rangga, maka ia juga berpikir untuk juga memaafkan kesalahan terbesar ibunya.

Rangga haus akan kasih sayang seorang ibu. Walau membenci tindakan ibunya di masa lalu, jauh di lubuk hati kecilnya, Rangga sangat menyayangi dan merindukan ibunya. Rangga membalas erat pelukan erat ibunya dan menangis. Tidak banyak dialog dalam adegan ini. Terlalu banyak yang harus dijelaskan untuk rentang waktu yang sangat lama dan terwakili dengan ekspresi dan tindakan pelukan di antara keduanya. Keduanya sama-sama merasa tersiksa dan membutuhkan satu sama lain.

Ekspresi Ibu terkejut melihat kedatangan Rangga. Walau sudah lama tidak bertemu, sosok ibu tetap masih bisa mengenali wajah anaknya. Rangga yang awalnya enggan membalas pelukan ibunya akhirnya luluh. Tidak banyak hal yang bisa dilihat dari pertemuan tersebut karena tidak ada dialog yang menjelaskan alasan kepergian ibunya pada masa lampau.

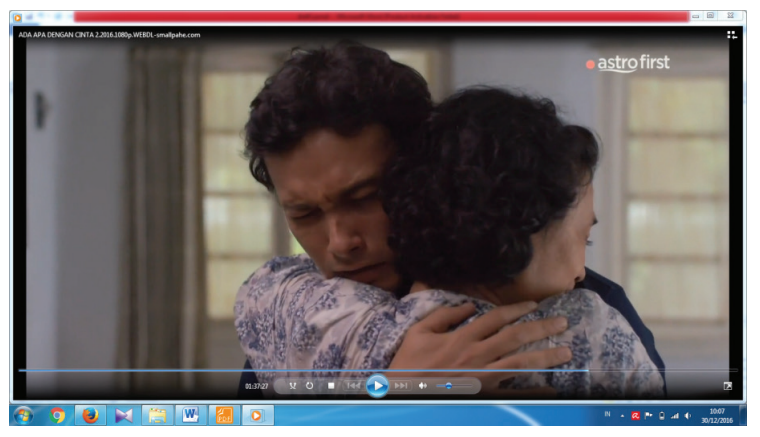

Gambar 8. Rangga membalas pelukan ibunya Capture timecode: 01:37:27 


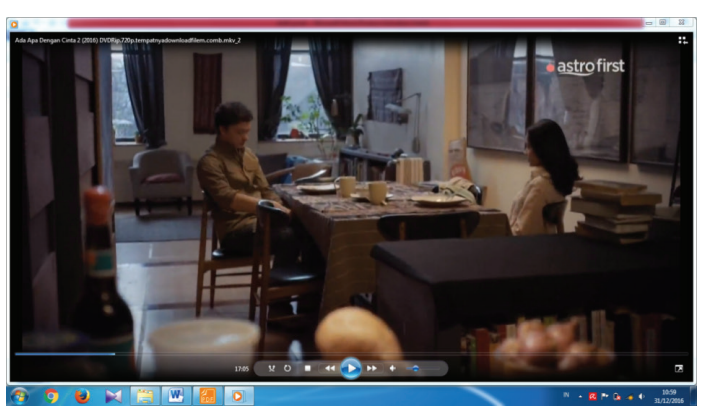

Gambar 9. Sukma memohon Rangga menemui ibunya Capture timecode: 00:17:05

4) Rangga dengan Sukma (adik tiri)

Sukma merupakan tokoh baru yang tidak muncul pada serial Ada Apa dengan Cinta sebelumnya. Sukma dimasukkan dalam cerita sebagai jembatan yang mengetuk hati Rangga untuk kembali ke Indonesia melalui kerinduan ibunya. Rangga sangat kaget dirinya memiliki seorang adik tiri. Walaupun sangat membenci ibunya, kedewasaan Rangga tidak membuatnya bersifat arogan terhadap Sukma. Sukma menemui Rangga di kafe. Rangga yang masih bersikap tertutup mengajak Sukma ikut ke tempat tinggalnya agar lebih bisa berbicara lebih serius karena memuat hal-hal pribadi.

Rangga menerima Sukma dengan terbuka dan mendengarkan permintaan Sukma dengan baik. Sukma yang menyentuh titik rawan mengenai ibunya, Rangga hanya bergejolak namun tetap bisa mengontrol dirinya. Sukma tetap memohon Rangga untuk mau menemui ibunya walaupun sangat sulit membuat Rangga menyadari bahwa dirinya masih memiliki seorang ibu. Rangga tetap bersikap baik bahkan menerima pelukan Sukma saat tiba di Indonesia. Rangga sadar Sukma tidak bisa menerima perlakuan kasar atas dasar kebencian Rangga pada ibu yang sama-sama melahirkan keduanya.

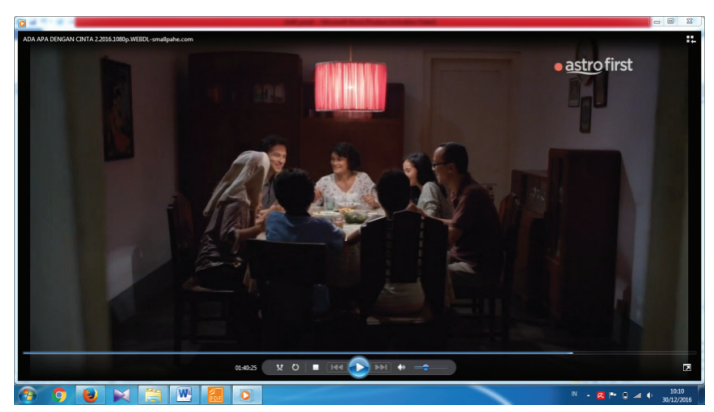

Gambar 10. Makan malam keluarga besar Rangga Capture timecode: 01:40:25

5) Rangga dengan keluarga

Kehangatan mulai terbangun saat Rangga bisa memaafkan ibunya. Sukma langsung menelepon keluarga besarnya untuk mengabarkan kepulangan Rangga ke Jogja. Keluarga besar Rangga berkumpul bersama lengkap dengan anak-anaknya. Keluarganya bercengkerama dan diakhiri dengan makan malam bersama. Rangga sudah empat belas tahun tidak pulang ke Indonesia. Kabar kepulangan Rangga membuat keluarga besarnya berkumpul dalam waktu singkat. Suasana pertemuan keluarga besar Rangga terasa hangat yang nampak dari ekspresi penuh senyum dan tawa.

\section{Konsepsi Tokoh}

1) Dinamis

Tokoh Rangga dalam film Ada Apa dengan Cinta 2 memiliki sifat yang dinamis, yaitu berubah-ubah menyesuaikan situasi yang ada. Berbeda dengan perwatakan dalam sekuel

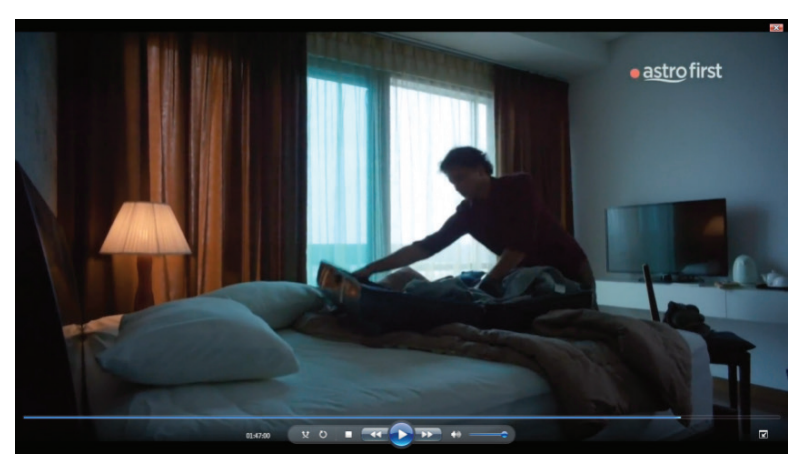

Gambar 11. Rangga membereskan pakaiannya dengan emosi

Capture timecode: 01:47:01 
sebelumnya yang pendiam dan acuh tak acuh (cenderung statis). Kini Rangga lebih bisa membaca situasi dan tidak egois. Rangga dapat bersikap sangat tenang, namun di lain scene Rangga dapat bersikap penuh emosi. Rangga yang pendiam dan tidak suka tersenyum juga bisa tertawa. Hal tersebut tergambar jelas pada respons dari pemain yang lain seperti Cinta dan sahabat-sahabatnya.

\section{2) Kompleks}

Rangga memiliki perwatakan yang kompleks. Perasaan bersalah dan kekecewaan yang mengakar di hatinya membuatnya harus berubah. Walaupun demikian, sifat dasar Rangga masih dipertahankan oleh Mira Lesmana hanya saja perubahan yang dilakukan memang lebih besar. Kompleksitas sifat Rangga digunakan sebagai jalan untuk menyelesaikan masalah rumitnya dengan Cinta ataupun keluarganya.

\section{Rangga: Pengusaha muda? \\ Cinta: (mengangguk) \\ Rangga: Pasti dia lahir udah kaya banget ya? \\ Cinta: Saya seharian sama kamu saya pikir kamu sudah berubah Rangga. Saya pulang sekarang}

Kutipan di atas menggambarkan bahwa Rangga masih memiliki sifat yang dipertahankan oleh penulis naskah. Sosok Cinta, satu-satunya perempuan yang sudah lama dekat dengan Rangga, sangat memahami sifat itu dan menyadari hal tersebut bagaikan watak yang sulit sekali diubah. Kata-kata dan nada sinis yang keluar dari mulut Rangga mengecewakan Cinta.

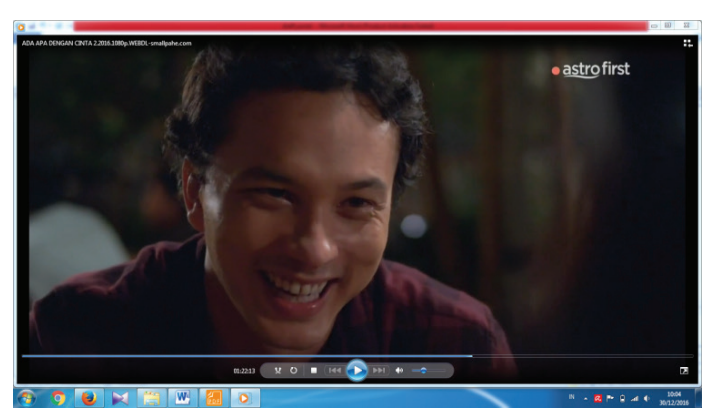

Gambar 12. Rangga tertawa saat bersama Cinta Capture timecode: 01:22:12

\section{3) Terbuka}

Watak Rangga dapat dibaca dengan jelas baik baik dari dialog maupun interaksi yang terjadi dalam film. Perubahan karakter Rangga yang terbuka sangat bertolak belakang dengan Rangga pada tahun 2002 yang sangat tertutup dan hampir tidak mengizinkan orang lain mengetahui sisi pribadinya. Rangga dapat dengan mudah mengekspresikan perasaan dan pikirannya sehingga hal yang terjadi dalam dirinya berupa perasaan, pikiran, keinginan dapat diketahui dengan jelas.

Dalam scene di atas, Rangga dapat bersikap terbuka terhadap perasaannya. Ekspresi Rangga ini bahkan hanya nampak saat bersama Cinta. Interaksi dengan Cinta membuatnya nyaman untuk mengungkapkan isi hatinya karena Cinta juga semakin terasa nyaman dalam menyikapi Rangga. Interaksi Rangga dengan tokoh lain tidak seaktif saat bersama Cinta.

\section{SIMPULAN}

Berdasarkan uraian di atas sangat terasa perubahan karakter Rangga yang dilakukan oleh penulis naskah. perubahan karakter Rangga dibuat sebagai penebusan rasa bersalahnya baik kepada Cinta maupun dirinya sendiri. Secara garis besar, masalah yang menimpa Rangga dalam hidupnya memengaruhi sisi psikologis, sosiologis, dan fisiologisnya. Karakter Rangga sengaja dibuat 


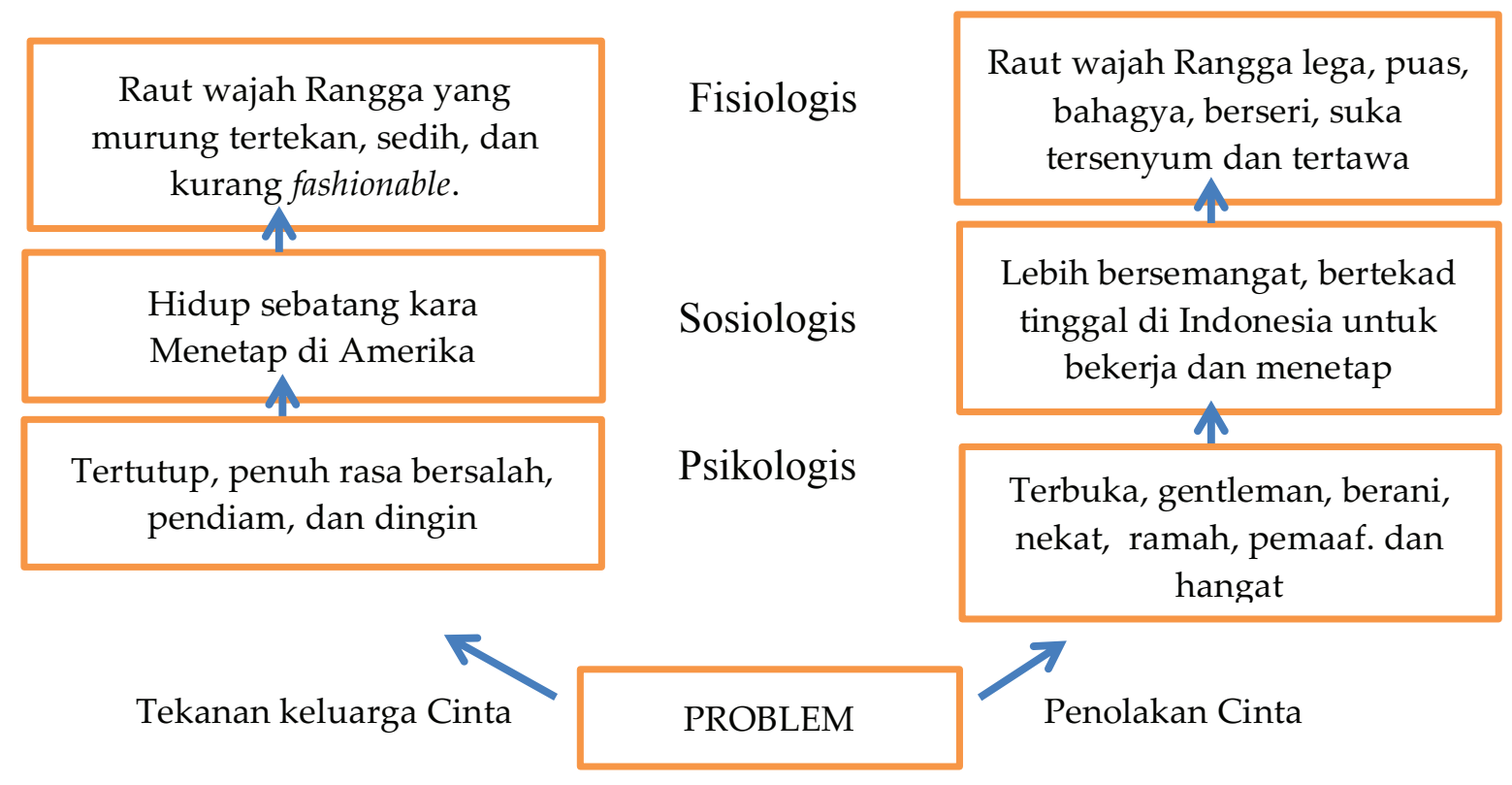

Gambar 13. Skema alur perubahan karakter Rangga

berbeda. Tokoh Rangga merupakan tokoh berkembang, yaitu mengalami perubahan dari awal cerita hingga akhir cerita melalui sebuah perjalanan. Tokoh ini berkembang dengan tahapan tertentu sesuai dengan masalah-masalah yang dihadapinya. Pola pengenalan karakter yang dibuat Mira Lesmana sesuai dengan skema berikut ini.

Dari skema di atas diketahui bahwa perubahan karakter rangga dilatarbelakangi sebuah tekanan yang terfokus pada karakter tokoh Cinta. Pada awal film karakter Rangga dibentuk oleh tekanan keluarga Cinta yang menuntutnya segera menyelesaikan kuliah dan segera melamar Cinta. Ketidakmampuan Rangga dalam memenuhi hal tersebut berujung pada perpisahannya dengan Cinta. Sedangkan pada skema bagian kanan merupakan alur perubahan karakter menuju akhir cerita yang dilatarbelakangi oleh penolakan Cinta bertemu dengan Rangga. Perubahan karakter Rangga dibutuhkan agar Cinta dapat kembali ke sisinya.

Perubahan karakter Rangga dibandingkan pada film Ada Apa dengan Cinta (2002) terletak pada sumber sakitnya, yaitu ibunya yang membuat sikapnya acuh dan dingin. Rangga tidak ingin memperbaiki hubungannya dengan ibunya. Dalam film Ada Apa dengan Cinta 2 (2016) bersumber pada tokoh Cinta. Untuk mengatasi berbagai masalah dalam hidupnya, tokoh Rangga dibuat sebagai karakter yang berkembang. Dasar Perubahan tokoh Rangga adalah tokoh Cinta yang akhirnya memengaruhi sisi psikologinya yang tercermin dari perilaku, hubungan sosial, dan fisiknya.

\section{KEPUSTAKAAN}

Biran, M. Y. (2006). Teknik Menulis Skenario Film Cerita. Jakarta: PT. Dunia Pustaka Jaya.

Boggs, J. M. (1992). The Art of Watching Film:

Cara Menilai Sebuah Film. (A. Sani, Trans.) Jakarta: Yayasan Citra.

Fitryan, D. G. (2009). Bekerja Sebagai Penulis Skenario. Jakarta: Erlangga.

Inna, M. A. (2005). Kepribadian Tokoh Utama Michael Berg dalam Roman Der Vorleser Karya: Bernhard Schlink: Psikologi Sastra. Yogyakarta: Jurusan Pendidikan Bahasa Jerman, Fakultas Bahasa dan Seni, UNY.

Lesmana, M. (Director). (2016). Ada Apa dengan Cinta [Motion Picture].

Lutters, E. (2004). Kunci Sukses Menulis Skenario. Jakarta: Grasindo. 
Minderop, A. (1996). Metode Karakterissi Telaah Fiksi. Jakarta: Yayasan Pustaka Obor Indonesia.

Noble, W. (2006). Konflik, Aksi, dan KeteganganMeramu Kisah Dramatis Menuju Klimaks dalam Cerita. Bandung: MLC.

Sidarta, S. S. (2003). Menjadi Penulis Skenario. Jakarta: Grasindo.

Sumarno, M. (1996). Dasar-Dasar Apresiasi Film. Jakarta: Grasindo.

Wicaksono, A. (2014). Pengkajian Prosa Fiksi. Yogyakarta: Garudhawaca. 